\title{
Administrative Discretion: The Next Stage
}

\author{
Martin Shapiro†
}

The history of American administrative law consists in large part of a game of procedural catch-up. Courts and legislatures attempted to control agencies' autonomy only after agencies came to wield substantive authority. This tardiness stemmed initially from the fundamental antipathy of Anglo-American jurisprudence to administrative law: Allegiance to the "rule of law" demanded that government officers be subject not to special rules invented for their benefit but to the same common law rules that governed private persons. ${ }^{1}$ This attitude finally crumbled under the weight of the New Deal's administrative activity. A decade after the New Deal had endowed the agencies with vast substantive power, Congress provided procedural rules for the exercise of that power in the Administrative Procedure Act of 1946 (APA). ${ }^{2}$

Because American administrative law represents such a tardy reaction, it has never pretended to be a complete body of law. Most procedural requirements are found in the variously worded and incomplete procedural provisions tacked onto the organic acts that establish particular agencies or programs. ${ }^{3}$ The APA is residual law for courts to use when there are gaps in those organic procedural provisions.

Because the APA was meant to control the greatly expanded adjudicatory activities of regulatory agencies, it contains relatively detailed rules for administrative adjudication, ${ }^{4}$ but says little about other forms of administrative action. In the three decades after passage of the APA, administrative agencies shifted increasingly from quasi-judicial adjudication to quasi-legislative rulemaking as their primary way of making policy. ${ }^{\circ}$ The

$\dagger$ Professor of Law, University of California at Berkeley, School of Law.

1. See A. DICEY, INTRODUCTION TO THE STUDY OF THE LAW OF THE CONSTITUTION 202-03 (1885); Shapiro, On Predicting the Future of Administrative Law, REGULATION, May/June 1982, at $18,18-19$.

2. Administrative Procedure Act of 1946, ch. 324, 60 Stat. 237 (codified as amended at 5 U.S.C. $\S \S 551-559,701-706$ (1982)) [hereinafter cited as APA].

3. See, e.g., Occupational Safety and Health Act of 1970, 29 U.S.C. $\S$ 655(f) (1982) (OSHA judicial standards should be based on substantial evidence); National Labor Relations Act, 29 U.S.C. $\$ \S 153-168$ (1982) (setting out National Labor Relations Board procedures).

4. See APA $\S \S 56-557$ (provisions governing procedures to be followed in administrative adjudications).

5. See Shapiro, The Choice of Rulemaking or Adjudication in the Development of Administrative Policy, 78 HARV. L. REV. 921 (1965); see also Pedersen, Formal Records and Informal Rulemaking, 
APA contains only a few cryptic words about rulemaking: It requires only that rules be made after "notice" and "submission of written data, views, or arguments," be published in the Federal Register, and be accompanied by a "concise general statement of their basis and purpose." 1960's and 1970's, the courts, led by the Court of Appeals for the D.C. Circuit, caught up to the substantive reality of greatly increased rulemaking by writing a detailed, judge-made code of administrative procedure for rulemaking. " Suitably winnowed, that case law seems likely to be incorporated into the revised APA that Congress will probably enact within the next few years.

Now that the courts have caught up with adjudication and then with rulemaking, what next? The APA essentially divides administrative action into three parts: quasi-judicial adjudication; quasi-legislative rulemaking; and a residual category, which I shall call "informal action."8 This Article discusses the nature of administrative actions in this residuum. First, it explores the "discovery" of administrative discretion and the courts' initial articulation of standards of review for discretionary action. It then locates the issue of judicial control of discretionary agency action in the larger context of American political development. Finally, it examines the various forms that discretion can take and speculates on the courts'. possible responses to these different types of agency behavior.

\section{The Idea of Agency Discretion}

\section{A. Giving the Residuum a Name: Discovering Administrative Discretion}

The APA sets up a strange gravitational attraction between the nonadjudicative, non-rulemaking residuum and discretion. It provides no procedural rules for the residuum and no specific standards for judicial review of informal actions. If courts are to review the residuum at all, they cannot do so for its adherence to the procedures of section 553 or sections 556 and $557 .^{\circ}$ Instead, they must look to the APA's general catchall standard of review. Courts may review any administrative action to determine whether it was "arbitrary, capricious, [or] an abuse of discretion." 10 "Ar-

85 YALE L.J. 38, 38-39 (1975) (it was "generally assumed" until early 1960's that regulatory schemes would rely primarily on adjudication).

6. APA § 553.

7. See $1 \mathrm{~K}$. DAVIS, ADMinistrative LAW TREATISE 447-634 (2d ed. 1978).

8. The APA gave no name to this third category. Informal action is not a wholly satisfactory term for non-adjudicatory, non-rulemaking action, in part because of the long tradition of referring to rules made under the APA $\S \S 556-557$ procedures as formal rules, and rules made under $\S 553$ procedures as informal rules. "Informal action," as I use the term here, does not include "informal rules."

9. The procedures specified in APA $\$ \S 553-557$ apply only to "rule making" and "adjudication." Section 706's provisions concerning the scope of review specify a standard only for adjudications. APA $\S 706(2)(\mathrm{E})$.

10. APA $\S 706(2)(A)$. 
bitrary and capricious" is the standard that courts normally use to review rulemaking under section 553; unless they wish to equate the standard by which they review action under section 553 and the standard by which they review the residuum, they must review such informal action for abuses of discretion. Now, if the courts are looking for abuses of discretion, it must follow that what they are looking at is exercises of discretion. Thus, although it is not logically or even empirically true that all informal agency actions are exercises of discretion, courts will typically label informal actions discretionary because the standard by which the actions are reviewed uses that label. ${ }^{11}$

\section{The Prosecutorial Model}

In 1969 Kenneth Culp Davis, a doyen of academic administrative law, discovered "discretionary justice."12 More precisely, he discovered that the police exercise discretion, a discovery already made by those who studied the police rather than administrative law. ${ }^{13} \mathrm{He}$ also discovered that prosecutors exercised discretion-another item not exactly news, at least to scholars of criminal justice. Davis's book is nevertheless often cited by courts, largely because Discretionary Justice is a convenient bibliographic symbol of the feeling of academics and judges that, having tamed administrative adjudication and rulemaking, they must now tame discretion.

\section{Fitting Administrative Discretion into the Framework of Administra- tive Law}

Difficulty in taming administrative discretion arises because there is a tendency to lump together all behavior that falls into this residual category, to analogize it to the discretion about which we know most, prosecutorial discretion, and to impose a unified theory upon it. This tendency to treat discretion as a single analytic concept is reinforced by the practical needs of administrative lawyers. If the APA exempts actions "committed to agency discretion" from judicial review, ${ }^{14}$ then we must discover precisely which actions are so committed in order to resolve crucial questions of judicial jurisdiction. Given the general inclination in the 1960's and 1970's to expand judicial control over agencies, much of the

11. It has become commonplace to point out that the APA provides both that "agency action ... committed to agency discretion by law" is excepted from judicial review, id. $\S 701$, and that "[t] he reviewing court shall . . . set aside agency action . . . found to be . . . an abuse of discretion," id. $\S$ 706. Courts have continuously narrowed the category of actions considered to be so discretionary as to be exempted from review. See infra pp. 1491-92.

12. K. DAVIS, DISCRETIONARY JUSTICE (1969).

13. See J. WILSON, VARIETIES OF POLICE BeHAVIOR 83-139 (1968).

14. APA \& 701 . 
original concern with discretion resembled a cowboy's attempt to cut as many as possible out of the unmarked herd and brand them as nondiscretionary, or at least as reviewable even if discretionary.

The principal device for ensuring reviewability was the judicially created doctrine that, despite the APA's language about actions "committed to agency discretion," courts may review an agency's action unless "there is no law to apply."15 Because virtually no administrative action occurs entirely outside of some statutory authorization, ${ }^{18}$ there is nearly always some law to apply. Thus, although informal action might not have to conform to the procedural standards of sections 553, 556, and 557, it is reviewable. As discussed above, the only distinct standard of review available is abuse of discretion.

\section{B. Gitizens To Preserve Overton Park, Inc. v. Volpe: Reviewing Admin- istrative Discretion}

Traditionally, claims of abuse of discretion involved four kinds of contentions: (i) the agency had considered an irrelevant factor; (ii) it had failed to consider a relevant factor; (iii) it had given improper weight to a relevant factor; or (iv) it had decided without sufficient evidence. ${ }^{17}$ All of these factors were involved in one of the first great signposts on the way to increased judicial review of informal action, Citizens to Preserve Overton Park, Inc. v. Volpe ${ }^{\mathbf{1 8}}$ In Overton Park, the plaintiffs challenged the Secretary of Transportation's decision to construct a superhighway that would bisect a park. They argued that the Secretary should have employed the procedures of section 553 or of sections 556 and 557. The Supreme Court rejected that claim, but held that the Secretary's action was reviewable and that the standard by which to review it was whether the action was "arbitrary, capricious, [or] an abuse of discretion."19 If the Secretary's informal administrative action involved "a clear error of judgment," it would be invalidated. ${ }^{20}$

Standards for judicial review are notoriously vague. The degree to which a court will substitute its judgment for an agency's is neither determined nor expressed by the formula it announces. A standard of judicial review expresses only a "mood."21 Changes in the language used to de-

15. Citizens to Preserve Overton Park, Inc. v. Volpe, 401 U.S. 402, 410 (1971).

16. At the very minimum, an agency's action must be dependent on the enabling statute that brought the agency into existence.

17. See Saferstein, Nonreviewability: A Functional Analysis of "Committed to Agency Discretion," 82 HARV. L. REV. 367, 368 (1968).

18. 401 U.S. 402 (1971).

19. Id. at $413-14$.

20. Id. at 416 .

21. Cf. Jaffe, Judicial Review: "Substantial Evidence on the Whole Record", 64 HARV. L. REV. 


\section{Administrative Discretion}

scribe the scope of review do, however, express changes in mood. To understand the change of mood represented by Overton Park, it is worth placing "clear error" in the context of earlier language concerning review of agency action.

\section{Standards of Review for Agency Adjudication and Rulemaking}

Originally, administrative adjudication was governed by the "substantial evidence" requirement, rulemaking by the "arbitrary and capricious" standard, and informal action by the "abuse of discretion" test. ${ }^{22}$ These standards for judicial review of agency decisions apparently stemmed from earlier efforts to articulate standards for appellate review of trial court proceedings and differed in the intensity of their scrutiny. ${ }^{23}$ None called for "de novo" review, that is, for independent weighing of the evidence by the reviewing body. ${ }^{24}$ Such appellate activism is extremely unusual in American criminal and civil procedure, and almost unheard of in judicial review of administrative proceedings. ${ }^{25}$

The substantial evidence test involves the most searching judicial scrutiny. Initially, the test required only that the reviewing court determine whether the agency had amassed substantial evidence on its side. ${ }^{26}$ If there was substantial evidence supporting the agency's determination, it did not matter how much evidence the other side had compiled. ${ }^{27}$ Eventually, however, the test became "substantial evidence on the record as a whole"28 and the substantiality of the agency's evidence was established only after the reviewing court had discounted the agency's evidence by considering rebuttal evidence. ${ }^{29}$ Thus, the court had to make some inde-

1233, 1236 (1951) ("ultimate effect [of Universal Camera Corp. v. NLRB, 340 U.S. 474 (1951)] is not so much to give guidance to the judges of the reviewing courts as to . . . indicat[e] the spirit or mood in which the judges should approach their task").

22. See APA $\S 706(2)(A)$ (requiring courts to overturn agency behavior found to be "arbitrary, capricious, an abuse of discretion, or otherwise not in accordance with law"); id. $\S 706(2)(\mathrm{E})$ (requiring "substantial evidence" in cases subject to $\$ \S 556-557$ rulemaking); W. GELLHORN, C. BYSE \& P. STRAUSS, ADMINISTRATIVE LAW: CASES AND COMMENTS 257-350 (7th ed. 1979).

23. See Stern, Review of Findings of Administrators, Judges and Juries: A Comparative Analysis, 58 HARV. L. REV. 70 (1944).

24. The APA calls for de novo review on an "unwarranted by the facts" standard in only a few narrow circumstances. APA $\S 706(2)(F)$.

25. See Glick, Independent Judicial Review of Administrative Rate-Making: The Rise and Demise of the Ben Avon Doctrine, 40 FordHAM L. REV. 305 (1971).

26. NLRB v. Universal Camera Corp., 179 F.2d 749 (2d Cir. 1950), rev'd, 340 U.S. 474 (1951).

27. See W. GELLHORN, C. BYSE \& P. STRAUSS, supra note 22, at 257-76; Jaffe, supra note 21, at 1234; Stason, "Substantial Evidence" in Administrative Law, 89 U. PA. L. REV. 1026, 1049-50 (1941).

28. See O'Leary v. Brown-Pacific-Maxon, Inc., 340 U.S. 504, 508 (1951); Universal Camera Corp. v. NLRB, 340 U.S. 474, 485 \& n.21, $487-88$ (1951).

29. See Universal Camera Corp. v. NLRB, 340 U.S. 474, 490-91 (1951); Jim Causley Pontiac v. NLRB, 620 F.2d 122, 123 (6th Cir. 1980). See generally Jaffe, supra note 21 (discussing Universal Camera's alteration of substantial evidence requirement). 
pendent assessment of both sides' evidence. If, however, a residuum of unrebutted agency evidence survived the discounting process and if that residuum was substantial, then the agency's action was upheld even if its decision ran against the weight of the evidence in the whole record..$^{30}$

Agency rulemaking was initially governed by a standard clearly less strict than either of the standards applied to adjudication. The requirement that rules not be "arbitrary and capricious" bore a strong family resemblance to the test employed by appellate review of jury verdicts. An agency was not required to show that its rule was supported by substantial evidence. Indeed, there was initially no evidentiary record in rulemaking proceedings, and courts generally presumed that the agency had evidence supporting its rule. ${ }^{31}$ As the requirement of a "rulemaking record" developed, ${ }^{32}$ however, the "arbitrary and capricious" test came to resemble the substantial evidence test because both asked essentially the same question: Could a reasonable policymaker facing the evidence spread before the agency arrive at the agency's conclusion? ${ }^{33}$

Finally, non-adjudicative, non-rulemaking informal agency action was either exempt from review altogether or subject to review only for abuse of discretion. ${ }^{34}$ The absence of a record requirement in informal nonrulemaking decisions eliminated judicial review of the sufficiency of the evidence. Instead, courts developed an essentially "good faith" review of such agency decisionmaking. If the agency appeared to have acted in good faith-without bias, prejudice, or fundamental unfairness-then courts would uphold its discretionary decisions without demanding any particular quantum of evidence.

In practice, as we have noted, the "substantial evidence" and "arbitrary and capricious" tests tended to merge after courts began to require records in rulemaking. If "abuse of discretion" were identical to "arbitrary and

30. See B. SCHWARTZ, ADMINISTRATIVE LAW 601-05 (2d ed. 1982).

31. See Pacific States Box \& Basket Co. v. White, 296 U.S. 176, 185 (1935) (if court can imagine any set of facts that would justify agency's determination, it must uphold agency's action); $c f$. Kotch v. Board of River Port Pilot Comm'rs, 330 U.S. 552, 562-64 (1947) (rejecting equal protection challenge because nepotism in selection process might conceivably be related to safety).

32. See Portland Cement Ass'n v. Ruckelshaus, 486 F.2d 375, 393 (D.C. Cir. 1973) ("not consonant with the purpose of a rule-making proceeding" to rely on inadequate or undisclosed information), cert. denied, 417 U.S. 921 (1974).

33. The courts often uttered the words "arbitrary and capricious" and "an abuse of discretion" with so little pause that the two tests might have been one. Surely, if one acts arbitrarily and capriciously, one also abuses one's discretion. In practice, however, there was a distinction between the two. As the rulemaking record requirement emerged, an agency confronting the arbitrary and capricious standard had to bring forward evidence in support of its rule. See Abbott Laboratories v. Gardner, 387 U.S. 136, 143 (1967); National Nutritional Foods Ass'n v. Weinberger, 512 F.2d 688, 705 (2d Cir. 1975) (Lumbard, J., concurring) ("In essence I think that when an agency engages in substantive rule-making, it abuses its discretion (or acts arbitrarily or capriciously) if its actions are not supported by substantial evidence."); Industrial Union Dep't AFL-GIO v. Hodgson, 499 F.2d 467, 485 (D.C. Cir. 1974); Pedersen, supra note 5, at 48-49.

34. See Associated Indus. v. United States Dep't of Labor, 487 F.2d 342 (2d Cir. 1973). 
capricious," then all three standards would now tend to merge. Nevertheless, both in theory and in "mood," a perceptible spectrum of severity ran from substantial evidence (adjudication) through arbitrary and capricious (rulemaking) to abuse of discretion (informal action). Because none of the words in any of the standards of judicial review had any extrinsic meaning, both Congress and the courts tended to express their feelings about the proper level of judicial deference toward agency decisionmaking by using language that moved toward one end of the spectrum or the other. Direction of movement, more than the words themselves, conveyed the mood.

\section{The Clear Error Standard and Review of Discretionary Agency Action}

Overton Park announced an explicit standard for review of informal action-"clear error of judgment." 38 These words have no more precise meaning than those of the earlier standards. They do, however, convey a movement toward the less deferential end of the review spectrum. "Substantial evidence" occupies a place somewhere between "weight of the evidence" and "arbitrary and capricious." "Clear error" resides in the same neighborhood. Indeed, it seems about a block closer to "weight of the evidence": An agency might have been guilty of clear error in striking the final evidentiary balance but nonetheless have had substantial undiscounted evidence on its side. ${ }^{37}$

This analysis suggests that Overton Park moved informal agency action from the least demanding point on the spectrum of judicial review-abuse of discretion - to the most demanding point-a point between "substantial

35. 401 U.S. 402,416 (1971).

36. Cf. Universal Camera Corp. v. NLRB, 340 U.S. 474, 487 (1951) (Taft-Hartley Act's change of standard of review in NLRA cases shows "mood [that] must be respected, even though it can only serve as a standard of judgment and not as a body of rigid rules").

37. In announcing this standard, the Court may not have remembered that judicial review of administrative proceedings resembles review by appellate courts of trial court proceedings. Without that resemblance, we might not know where to place "clear error of judgment" along our spectrum of review standards. When the resemblance is taken into account, however, a rather startling result emerges. If "against the weight of the evidence" is the standard of de novo review, and "arbitrary and capricious" is the standard for review of jury trials, then "clear error" is the standard for review of non-jury trials, see Lundgren v. Freeman, 307 F.2d 104, 113-15 (9th Cir. 1962). Appellate courts must respect the findings of juries unless the findings are beyond the bounds of reason, but they owe findings of a trial court judge sitting alone somewhat less respect. To avoid de novo review, appellate judges will not reverse a trial court just as factfinder simply because they would have come to a different conclusion on the weight of the evidence. But they will reverse when the trial judge has made a clear error. "A finding is 'clearly erroneous' when although there is evidence to support it, the reviewing court on the entire evidence is left with the definite and firm conviction that a mistake has been committed." United States v. United States Gypsum Co., 333 U.S. 364, 395 (1948); see FED. R. CIV. P. 52(a). In short, the clearly erroneous standard expresses reviewing court deference to the trial judge, but not quite so much deference as is due to a jury. 
evidence" and "against the weight of the evidence." This conclusion is bolstered by whatever the phrase "clear error" means. Clear error must be a species of error. In employing this standard, a judge must decide whether the agency was in error or not in error, and then whether the degree of error was great enough to be characterized as clear. This certainly looks like an independent weighting of the evidence with the agency given only the benefit of the doubt.

All of this is not to say that Overton Park, by substituting "clear error" for "abuse of discretion," compels courts to review informal nonrulemaking action more actively than they review informal rulemaking under the traditional "arbitrary and capricious" standard. Nevertheless, the use of "clear error" language appears to be a movement toward the less deferential end of the spectrum. As my use of the metaphors of spectrum, neighborhood, and family resemblance is meant to suggest, it would be quite unrealistic to create a formal system of degrees of deference out of these open-textured legal materials. They do, however, seem to yield the result that informal non-rulemaking activity is to be reviewed under a standard at least as strict as that for informal rulemaking, and perhaps an even stricter one.

Although the Supreme Court itself has not appeared very fond of the "clear error" language in Overton Park, the D.C. Circuit has been very fond of it indeed..$^{38}$ If we combine "clear error" with "so long as there is law to apply," we have constructed the springboard from which the next great leap forward of judicial review of administrative decisionmaking may occur. The previously invented standards-"substantial evidence" and "arbitrary and capricious"- have done triple duty as evidentiary standards, procedural standards, and substantive review standards. There is every reason to believe that "clear error" has the same potential to spread the new judicial review of informal action into all three realms.

Thus, the historical tendency of administrative law's move from adjudication to rulemaking to informal action means we should now focus on the informal actions of government that used to be called discretionary. All students of administrative law know, however, that elements of what was, and often still is, called discretion are also liberally scattered through administrative adjudication and rulemaking; there are often a number of alternatives, no single one of which is dictated by the law and the facts. Such situations arise in the procedural aspects of adjudication (e.g., agency decisions to limit cross-examination) as well as throughout the rulemaking

38. A LEXIS search showed 83 invocations of the test by the D.C. Circuit between May 10, 1972 and March 22, 1983. 
process. Our concern with control of agency discretion therefore encompasses a broader area than merely informal agency action.

\section{Administrative Discretion in Its Wider Political Context}

So far this discussion has proceeded as if administrative law, once triggered by the New Deal, developed autonomously. Outside forces were also important, however, and they are particularly important in explaining the current situation. At the same time that administrative law is apparently moving toward greater restraints on agency discretion, a number of commentators have been calling for greatly expanded agency discretion. Bruce Ackerman and William Hassler have suggested a return to the New Deal's broad delegations to those agencies whose enormous discretion is justified by their technical expertise; ${ }^{39}$ Richard Stewart has proposed a shift away from "command" processes, like adjudication and rulemaking, toward bargaining and negotiation. ${ }^{40}$ Stewart acknowledges that such a shift would increase agency discretion, and calls for judicial review. ${ }^{41}$ Both proposals seem opposed to the prediction that administrative law is now poised to catch up with and limit discretion as it earlier caught up with and limited adjudication and rulemaking.

To some extent, however, these crosscurrents prove my point. The calls for increased discretion recognize that discretion, particularly in rulemaking, has been so restricted by legal rules, emanating from both Congress and the courts, that it is time to take a new tack.

\section{A. The Tension Between Democracy and Technocracy}

The Ackerman-Hassler and Stewart proposals reflect a cycle of American politics that alternately assists and impedes the movement toward greater legal restraints on agency action. From the founding of the republic, Americans have embraced two opposing modes of public administration, the democratic and the technocratic. The former, which we might term the Jacksonian tradition, calls for government by the common people themselves, or at least by administrators directly representative of and responsive to the people. Rotation in office through the spoils system illustrates this tradition. As parties win and lose presidencies and governorships, their loyal partisans, themselves drawn broadly from the lay population, move in and out of administrative office. ${ }^{42}$

39. B. ACKERMAN \& W. HASSleR, ClEAN COAL/DiRTy Air (1981).

40. Stewart, Regulation, Innovation and Administrative Law: A Conceptual Framework, 69 CALIF. L. REV. 1259, 1341-53 (1981).

41. Id. at 1348.

42. See Shapiro, supra note 1, at 21. 
The opposing, Federalist tradition, first advocated by Hamilton, stresses the need for efficient government and thus the need for an administration staffed not by an ever-changing stream of Know-Nothings, but by experts. ${ }^{43}$ The Progressive movement inherited this tradition, and its civil service "reform" rooted out the spoils system. The corps of civil servants it created was not only permanent, thus acquiring technical expertise on the job, but was recruited through an examination system that tested technical competence to do a particular job rather than general education or management capacity. ${ }^{44}$ The Progressives even extended this meritocratic ideal to replace certain elected chief executives with technocrats. The regulatory commissions they established created whole governments in miniature, possessing legislative, executive, and judicial functions, that could be run by "non-political" experts.

\section{B. The New Deal}

The New Deal was the culmination of this technocratic tradition. It flooded Washington with agencies overwhelmingly staffed by technically trained specialists who soon achieved permanent civil service status. ${ }^{45}$ The watchword of administration became expertise, and the key doctrine of judicial review of administrative action became deference to that expertise. Discretion and expertise became synonymous. ${ }^{46}$

The democratic and technocratic traditions do not alternate with one another in some mechanical way. Both traditions are always alive, but there are periods in which one clearly dominates the other. Thus, although the New Deal's predominant strain was technocratic, New Dealers were also aware of democratic traditions. Particularly among New Deal ideologists, there was a need to bridge the contradictions between democracy and technocracy. They did so through concepts of representative bureaucracy and public interest. If we no longer had the direct de-

43. See id. at 19.

44. See Shapiro, Judicial Activism, in THE THIRD GeNTURY: AMERICA AS A POST-INdustrial SOCIETY 109, 121 (S. Lipset ed. 1979).

45. Id. at 121-23.

46. See J. LANDIS, THE ADMINISTRATIVE PROCESS 23-26, 31 (1938); Shapiro, supra note 44, at 123; Shapiro, supra note 1, at 19; Stewart, The Reformation of American Administrative Law, 88 HARV. L. REV. 1667, 1677-78 (1975). The technocratic character of the New Deal is sometimes obscured, particularly in the context of regulation, because the New Deal's major regulatory initiatives were in such areas as labor relations and securities markets. In these areas, the regulators spoke "law" rather than "science." Technocracy should not be confused with technology in the narrow sense of applied physical and biological science. The New Deal did bring many technologists in that sense into the Department of Agriculture, the Bureau of Standards, and other agencies. It also conceived of itself as bringing experts in social work, labor relations, public utility management, and corporate securities into other agencies, persons just as technically expert in their respective fields as the soil chemists and foresters were in scientific technologies. The hallmark of technocracy is not the language of the hard scientists, but rule by specialists in particular areas of human endeavor. 
mocracy of the spoils system in which the people themselves rotated through administrative offices, we had replaced it with a representative administrative bureaucracy. in which the bureaucrats were, somehow or other, as representative of the American people as were its elected representatives. Alternatively, the bureaucracy itself was seen as democratic, because public administration served "the public interest"-that is, the interest of the people. ${ }^{47}$

\section{The Middle Decades}

This ideological whitewash was soon replaced by a new theory and practice of administrative democracy. As the New Deal receded in the 1950 's and finally came apart in the welter of conflicts over race, Vietnam, and the environment, technocracy lost its dominant position. A group theory of politics arose in its place, emphasizing group access to, and domination of, the administrative decisionmaking process. ${ }^{48}$ The theory, which came out of ethical relativism and positivism (or, to say the same thing, utilitarianism) denied that there was a public interest or a true set of public values. ${ }^{49}$ The definition of "the good" became procedural. Whatever policy emerged from a decisionmaking process in which all relevant interests participated was good policy. Thus, the key to administration was participation. Bureaucrats would become democrats by reflecting the voice of the people as expressed to them by the interest groups.

The New Deal had created the problem of discretion vested in experts. New Deal lawyers solved this problem by making administrative adjudication more judicial and abandoning most of the rest of administration to technocracy. ${ }^{50}$ The swing during the 1950's toward democratic administration in the form of group politics led to the next step in legalization. Lawyers, the courts, and Congress busied themselves in creating procedural rules to limit administrative discretion by forcing administrators to give access to interest groups. ${ }^{51}$ These procedural limitations on administrative decisionmaking imposed not only legal limits on agency discretion but also democratic limits: The procedural requirements ensured that agencies would submit themselves to the democratic process of group struggle. The expansion of the law of standing, and the creation of new notice and comment or hybrid rulemaking processes are, of course, the principal examples. Since the 1950's, then, the particular balance struck

47. See Shapiro, supra note 44 , at 121 .

48. See Shapiro, supra note 1, at 19.

49. See id. at 20.

50. See Shapiro, supra note 44 , at 121-22.

51. See Shapiro, supra note 1 , at 20-21. 
between democracy and technocracy has helped administrative lawyers to bring yet another area of administrative action-rulemaking-under a regime of legal rules. This congruence between the technocratic-democratic cycle in public administration, and administrative law's internal, ruleimposing dynamic created the appearance of an inevitable teleology in administrative law, a teleology demanding that first adjudication, then rulemaking, and finally the rest of administrative decisionmaking be brought under legal rules enforced by judges.

As the cycle continued, however, this teleology became muddied. The 1960's and 1970's were a low point in American faith in expertise; group theory lost much of its legitimacy. ${ }^{\mathbf{6}}$ Critics charged that experts served not the public interest but self-interests deeply entangled with narrow private interests. The end result of struggles among groups was no longer inherently good because, to paraphrase Orwell, some groups were far more equal than others. ${ }^{53}$ If the American people rejected both technocracy and group access, what choice of administrative style was left? One answer was none. Jimmy Carter, Ronald Reagan, and a host of other politicians ran for office on a platform of simple opposition to government. $^{54}$

The other administrative style still available was government by judiciary. If group access was not an adequate democratic control over administration, judicial review might be. The judge was not a technocrat but a common person, who knew as little about highway construction, atomic energy, poultry science, and sewage treatment as any other citizen. ${ }^{\mathrm{B}}$ Through "partnership" and "hard looks," judges, as representatives of the people, could restore some element of democratic administration untainted by group self-interest or technocratic specialization.

The judiciary's first reaction was to use its new-found legitimacy to impose more rules on technocrats. These rules, however, were designed largely to implement an increasingly unpopular theory of democratic administration-the group theory. The new judge-made rules were procedural rules for group access. From this beginning, however, the invention of new rules on an ad hoc, ex post basis also frequently served to disguise the judges' new role as armed representatives of the demos. Courts were most likely to discover a new procedural rule when an agency's action appeared to be the poor product of an excessive narrowing of technocratic perspective-that is, when it showed the dark side of expertise. Each new

52. See id. at 22-23; Shapiro, supra note 44 , at 123-26.

53. See L. JAFFE, JUDICIAL CONTROL OF ADMINISTRATIVE ACTION 13 (1965) (discussing industry and pressure-group "capture" of agencies).

54. See Shapiro, supra note 1 , at 25.

55. See Shapiro, supra note 44 , at $125-26$ ("judge as post-industrial hero"). 
procedural invention both struck down a bad technocratic decision and improved group access, and thus seemed to further both the technocratic and the democratic ideals.

\section{The Current Situation}

By 1980 , however, technocratic themes and a certain disillusion with democratic administration began to reemerge. The contempt for technocracy of the 1960's and 1970's had been bolstered by the widely held belief that we produced so much and were so efficient that we could willingly accept considerable technical inefficiency as the price of bringing technocrats to heel.

By 1980 , productivity was once again a major American concern, and we were casting eyes at the Japanese as models of technological efficiency. In such a setting, renewed allegiance to technocracy was not simply a nostalgic "return" to the New Deal but also the next episode in a technocratic tradition stretching back to the founding of the republic. If productive efficiency is again our watchword, then discretion must be vested in those who know how to do things.

Both the book by Ackerman and Hassler and the article by Stewart explicitly acknowledge that their purpose is to accommodate environmental goals to the need for economic efficiency. ${ }^{56}$ Indeed, Stewart argues that environmental improvement can come only through technical antipollution innovations piggybacked on improved productivity. ${ }^{57}$ These authors work against a background of increasing calls for rationality in the regulatory process. Regulatory impact statements and cost-benefit analyses are much in the air. ${ }^{58}$ Even judges have made a subtle shift from demanding that the agencies listen and respond to all outside comments to demanding that they learn all the facts and consider all the alternatives. ${ }^{59}$ That is precisely the shift from democracy, in its group-politics version, to technocracy. The agency need not act democratically, only rationally, correctly, and efficiently. In short, it can return to expert decisionmaking. ${ }^{60}$

Ackerman and Hassler, reacting to the economic and technical irrationality of a Congress dominated by group politics, and Stewart, fearful of potential inefficiencies caused by government commands to industry, call for a return to technocratic discretion. Ackerman and Hassler apparently

56. See B. ACKERMAN \& W. HASSLER, supra note 39, at 59-78; Stewart, supra note 40, at 1261.

57. Stewart, supra note 40 , at $1288-1310$.

58. The concern is most clearly evidenced in President Reagan's requirement that proposed major rules be submitted to OMB for such cost-benefit analyses. Exec. Order No. 12,291, 3 C.F.R. 127 (1982).

59. See National Lime Ass'n v. EPA, 627 F.2d 416, $451-54$ (D.C. Cir. 1980). (1981).

60. See Diver, Policymaking Paradigms in Administrative Law, 95 HARV. L. REV. 393, 428-34 
vest discretion solely in agency technocrats, although one version of their program would give some discretion to industry acting under market constraints. ${ }^{61}$ Stewart vests discretion not in the agency but in a bargaining or negotiation process in which agency and industry technocrats join. The goal is environmental and safety policies that are not only rationally costeffective in and of themselves, but fully compatible with maximum economic growth. ${ }^{62}$

Against this background, we should consider the wide range of discretionary situations, and speculate on how, and the degree to which, such discretion can be brought under legal rules. ${ }^{63}$ In the remainder of this paper, I set out a tentative typology of administrative discretion and explore the courts' potential responses to these various forms of agency activity.

\section{A Typology of Administrative Discretion}

There are a variety of forms that discretionary agency action might take. One species-which we might term "traditional" discretion-occurs in a variety of normal agency activities. The other-the "new" discretion-has appeared as part of the current trend towards technocracy.

\section{A. Traditional Discretion}

Agency activity has long been marbled through with discretionary behavior. The courts' response to these various discretionary activities is likely to depend crucially on the particular situation involved.

\section{Distributive Decisions}

Some agency decisions involve the allocation of scarce resources when no legal rights or entitlements have been vested in particular individuals.

61. See B. ACKERMAN \& W. HASSLER, supra note 39, at 124-27.

62. See Stewart, supra note 40 , at 1377.

63. There is a rather standard repertoire of possible constraints on administrative discretion. In roughly descending order of severity they run: (1) creating substantive standards, rules, and statements of purpose that constrain the range of lawful agency choice; (2) creating procedural rules for constraining the process by which the agency makes choices; (3) requiring the agency to create its own substantive rules; (4) requiring the agency to create its own procedural rules; (5) requiring the agency to establish and follow precedents; (6) requiring the agency to give reasons. Professor Rabin, a contributor to this Symposium, has thoroughly explored the last option in Rabin, Job Security and Due Process: Monitoring Administrative Discretion Through a Reasons Requirement, 44 U. CHI. L. REV. 60 (1976), and Professor Yellin relies heavily on this approach in his contribution to this Symposium, see Yellin, Science, Technology, and Administrative Government: Institutional Designs for Environmental Decisionmaking, 92 YALE L.J. 1300 (1983). The first strategy is designed to eliminate discretion and is explored in the traditional debate on the non-delegation doctrine. The second and fifth are an integral part of the jurisprudence of administrative adjudication and notice-and-comment rulemaking. The third and fourth are forcefully espoused by Professor Davis. See K. DAVIS, 2 ADMIINISTRATIVE LAW TREATISE 157-213 (2d ed. 1979). 
An agency may take the position that many legally qualified applicants exist and that it has neither the statutory mandate nor the administrative means to distinguish among them. ${ }^{64}$ Accordingly, it creates no standards or criteria for such a choice and limits its procedures to the bare minimum necessary to ensure that the applicants are legally qualified. The assignment of public housing units in the face of substantial excess demand is a good example. In Holmes v. New York City Housing Authority, ${ }^{65}$ the agency essentially threw out pending applications every six months, and matched incoming applications with newly occurring vacancies by having desk workers thumb through the files until they found an applicant who matched the vacancy. If we assume good faith on the part of the desk workers, this process seems eminently fair, since it consists of a random selection among equally qualified claimants for a scarce benefit that only a few can receive.

The Second Circuit, however, was unwilling to assume such good faith in the face of potential bribery or favoritism. Moreover, the agency did not claim that its policy was intentionally random. Indeed, it suggested that the desk workers were trying to choose some applications as somehow better than others. ${ }^{68}$ In light of this implicitly merit-based allocation, the court required the agency either to institute a non-discretionary process (such as first-come, first-served) or to create an actual standard for choosing among the qualified. ${ }^{\text {tr }}$

That there is not enough to go around may justify random or firstcome, first-served distribution; it does not justify arbitrary distribution. I have little doubt that courts will increasingly either demand articulated standards, adherence to precedent, and the provision of reasons for decision or insist upon a truly random allocation. This trend toward limited administrative discretion will, however, be slowed by the factors discussed in the following two sections.

\section{High-Volume, Low-Level Decisions}

Some agencies must make a great many decisions, none of which has a very significant effect. Due to the volume of cases, the costs of even minimum procedural guarantees are high. For this reason a great deal of "negative" discretion goes unchecked. ${ }^{68}$ Allowing agencies substantial neg-

64. See Gellhorn \& Robinson, Perspectives on Administrative Law, 75 COLUM. L. REV. 771, 792-93 (1975). Ronald Dworkin refers to this type of decision as "distributive." See Dworkin, Hard Cases, 88 HARV. L. REV. 1057, 1067-68 (1975).

65. 398 F.2d 262 (2d Cir. 1968).

66. Id. at 263 (citing New York City Housing Authority resolution that Authority prefers "certain specified classes of candidates").

67. Id. at 265.

68. The issuance of parking tickets is a good example of high-volume, low-level discretion. Inter- 
ative discretion is most defensible when an agency is asked to allocate a great many insignificant goods to which no particular individuals have a legal entitlement. It is not so much that discretion is desirable as that the costs of controlling it seem to outweigh the meager benefits yielded by such controls.

Not only is the game not worth the candle, but the administrative costs of recordkeeping or reason-giving may severely deplete available resources. ${ }^{69}$ Judicial reluctance to impose elaborate due process requirements on various welfare programs may stem from a "welfare pool" theory of legislative behavior: ${ }^{70}$ If legislatures appropriate only a fixed pool of monies for a given welfare program, then that sum must be divided between benefit payments to the poor clients of the program and salaries to the middle-class bureaucrats who staff the programs. Imposing more rigorous due process requirements, and thus higher administrative costs, transfers tax dollars from the poor to the middle class. Of course, legislatures may treat the costs of more elaborate process as add-ons rather than extracting payment for them from the pool. If so, due process costs remain worth considering in terms of overall cost-benefit balances for the agency but cease to impose transfer payments from the poor to the middle class.

Goldberg v. Kelly ${ }^{71}$ and its progeny show that courts may reject unbounded discretion when they view the benefit an agency confers as an entitlement. In such cases, the benefit conferred is by definition neither scarce nor small. Instead, it must be given to all who are entitled regardless of procedural costs. ${ }^{72}$ A legislature may create statutory entitlements

nal review of small random samples of day-to-day performance, the preservation of a bare-bones factual record (e.g., the date, time, meter number, a license number, and officer's name on the parking ticket), and review of factfinding (e.g., "Your honor, my car was in the shop that day so it couldn't have been parked there.") are all possible responses. We are not prepared, however, to require parking officers to keep track of every instance in which they choose not to give tickets. Furthermore, the low-cost option of eliminating discretion and ordering officers to ticket every violation may prove unsatisfactory as irate motorists employ political pressure, if not physical violence, against ticketing automatons that will not listen to the homeowner who has parked in his own driveway while opening his garage door.

69. See Mashaw, The Management Side of Due Process: Some Theoretical and Litigation Notes on the Assurance of Accuracy, Fairness and Timeliness in the Adjudication of Social Welfare Claims, 60 CORNELL L. REV. 772, 778-79 (1974); Verkuil, The Search for a Legal Ethic: The Adversary System, Liberalism and Beyond, 60 Soundings 54, 63-64 (1977).

70. See W. GellHORN, C. BySE \& P. STRAUSS, supra note 22 , at 448 n.6.

71. 397 U.S. 254 (1970).

72. This is not to say that courts do not balance the administrative costs against the individual interest in the entitlements to arrive at the precise level of due process required, see Mathews v. Eldridge, 424 U.S. 319, 334-35 (1976), but only that once an entitlement is declared, the agency will no longer be permitted total discretion. See Griffeth v. Detrich, 603 F.2d 118 (9th Cir. 1978) (requiring due process for state and local welfare applicants where entitlement found under state and local rules); Geneva Towers Tenants Org. v. Federated Mortgage Investors, 504 F.2d 483 (9th Cir. 1974) (imposing requirement of notice, comment, and explanation where entitlement to federally funded housing found). For commentary on due process and its costs, see Simon, Liberty and Property in the Supreme Court: $A$ Defense of Roth and Perry, 71 CALIF. L. REV. 146 (1983); Van Alstyne, Cracks in 
to try to prevent itself from meeting the costs of due process by reducing benefits. The legislature can then rely on the courts to force it to treat the costs of due process as add-ons. But unless courts specify the exact monetary level of the entitlements they declare, financially hard-pressed legislatures may try to recapture some portion of the costs of due process from the benefits flow.

\section{Subtle and Complex Assessments of Human Characteristics}

Some agency decisions involve such subtle and complex human factors that the agency may argue that it needs unbounded discretion. In cases like Holmes, ${ }^{73}$ an agency might argue that in picking tenants for public housing it should consider the likelihood of family disintegration if housing were not provided, the potential for improved family relationships, and the effect of various determinations on the sense of community in the projects. Such judgments should be left to the expert and subjective perceptions of decisionmakers, who have seen thousands of files and followed up on thousands of placements, rather than reduced to rules, precedents, and reasons. Such claims are most believable when an agency has the staff and information-gathering capacities actually needed to make such subtle, particularized judgments. In some areas, such as child placement, agencies can claim expertise and demonstrate that their decisionmakers are given the time and information necessary to make highly particularized judgments. Courts hearing such cases often reject most constraints on agency discretion. ${ }^{74}$

In the absence of such capacity, discretionary activity is likely to be subjected to substantial control even when we acknowledge that discretion ideally should be exercised. Courts are likely to make the agency produce standardized profiles of the most worthy applicants so that decisionmakers, in no position to make subtle, correct judgments, can make unsubtle, standardized judgments which can be reviewed for arbitrariness. ${ }^{75}$ When judgments are highly particularized and rest on the totality of a large number of factors, however, standards may in fact be useless because they can do no more than list a large number of factors to be considered; nearly any decision can somehow be justified in terms of that

"The New Property": Adjudicative Due Process in the Administrative State, 62 CoRnell L. REv. 445 (1977).

73. See supra p. 1501.

74. See Note, Child Custody: Substantial Justice Toward Children or Procedural Purity for Parents?, 7 U. DAYTON L. REv. 217 (1981).

75. This would seem to be the response of the court in the Holmes case itself. See Holmes, 398 F.2d at 265. For similar recommendations with respect to state education at the graduate level, see Gellhorn \& Hornby, Constitutional Limitations on Admissions Procedures and Standards, 60 VA. L. REV. 975, 1002-08 (1974). 
list. Requiring reasons would either impose very high administrative costs, as experts seek to write out a particular account of their complex thought processes, or would degenerate into an inventory of routine formulas to be attached to each decision. Requiring that precedent be followed suffers from a similar difficulty: Decisions simply recorded, without reasons given, cannot be used as precedents. In light of these difficulties, courts are likely to eschew substantive review of decisions involving complicated assessments of human characteristics, and instead impose procedural safeguards to ensure that sufficient attention is paid to each case by really expert, particularized decisionmakers and to guarantee that internal review proceedings, in which one expert checks on another, are available. ${ }^{78}$

\section{Agency Waivers}

Where the uniform application of a rule generates a small number of random, unforeseeable inequities-either absolute hardships or instances of one person being treated more harshly than most others-we may want to give agencies the discretion to grant waivers. ${ }^{77}$ The less random and more anticipated the inequities, and the higher their numbers, the more we should be alert for pseudo-waivers-that is, for the employment of discretionary waivers when a new rule should be made. The problem of pseudo-waivers becomes acute when the regulated parties are a few very large firms: Modifying the application of a rule for one has a major impact on the policy as a whole. It is also acute when an exceptions or waiver process is employed not to relieve those who suffer from highly individualized and unforeseeable harms but to relieve whole classes of persons or enterprises on the basis of shared characteristics which were or could have been foreseen. ${ }^{78}$ In such instances, an exceptions or waiver process easily becomes a form of back-door discretionary rulemaking freed from the rigors of notice-and-comment procedures. In such cases, an agency writes a single rule for all and then establishes patterns of exceptions or waivers that actually constitute subsidiary policy. Of course, legislatures often pave the way for this kind of agency behavior by passing statutes that impose overly severe rules and by adding waiver provisions through which they intend for agencies to apply their prescriptions in a more discriminating fashion.

76. See J. Mashaw, BUREAUCRATIC JUSTICE 194-227 (1983).

77. See Schuck, When the Exception Becomes the Rule: Regulatory Equity and the Formulation of Energy Policy Through an Exceptions Process, 1984 DUKE L.J. 163, 283-89; see also Aman, Administrative Equity: An Analysis of Exceptions to Administrative Rules, 1982 DUKE L.J. 277 (discussing role of exceptions in administrative equity).

78. See Schuck, supra note 77 (describing "class exception" from 1979 gasoline allocation regulations). 
Faced with such agency behavior, courts must ask whether what they are asked to review resembles a highly particularized plea for equity or policymaking by exception. ${ }^{79}$ If they face policymaking by exception, courts are likely to insist on something like the rules for hybrid rulemaking that encourage third party intervention. To the degree that waiver proceedings are seen as essentially equitable, the only relevant parties are the individual complaining of the injustice and the government agency whose actions he alleges to be unjust. When, however, waivers involve whole classes of persons seeking a special rule or class exemption, then there are many other relevant parties-various "public" interests and those who will have to continue under the general rule because they are not of the class seeking the special rule or exemption. Such multi-party, policy-oriented proceedings must inevitably suggest to courts the standard procedural solutions, namely notice-and-comment proceedings under section 553, as elaborated by the cases of the 1960's and 1970's.

\section{Thematic Statutes}

I noted earlier that although the historical dynamic is moving administrative law beyond adjudication and rulemaking, huge areas of discretion remain uncharted. One of the most intransigent consists of circumstances in which agencies are faced with "thematic" statutory commands to take into account a number of goals or factors but are given no assignment of relative weights to those factors. One can imagine statutes of this sort arranged along a spectrum. At one end lie those statutes which, in announcing a number of purposes, state priorities or weights as clearly and exactly as they can.$^{80}$ At the other end lie "lottery" statutes in which contending forces in the legislature, unable to agree on weights, placed all their contending preferences in the statute as the only available alternative to having no statute at all. ${ }^{81}$ In the latter cases, the legislators submit the

79. See Comment, The Exceptions Process: The Administrative Counterpart to a Court of Equity and the Dangers It Presents to the Rulemaking Process, 30 EMORY L.J. 1135 (1981).

80. One example would be statutes that give a specific number of bonus points to veterans on civil service examinations. These statutes specify exactly how much weight is to be given to the purpose of rewarding veterans as against the weight to be given to the purpose of maintaining an efficient service. See Fleming \& Shanor, Veterans' Preferences in Public Employment: Unconstitutional Gender Discrimination?, 26 EMORY L.J. 13, $17 \mathrm{nn} .12$ \& 14 (1977) (citing various state and federal preference formulas).

81. The 1940 amendments to the Interstate Commerce Act of 1887, for example, emerged from struggles among railroads, truck lines and barge lines. The purpose of the Act was couched in the following terms: "It is hereby declared to be the national transportation policy of the Congress to provide for fair and impartial regulation of all modes of transportation . . . so administered as to recognize and preserve the inherent advantages of each . . . . Transportation Act of 1940, ch. $722, \S$ 1, 54 Stat. 898, 899 (1940). The Act also mandated "reasonable charges for transportation services .. [and] fair wages." Id. It was therefore essentially nothing more than a vague instruction to the ICC about how to use its broad discretion to set rates. 
weighting to the administrative agency for a decision essentially random in the eyes of the legislators; they cannot anticipate which meaning the agency will adopt. The middle of the spectrum involves statutes in which legislators have provided some information about weights and therefore can partially anticipate the choices of the administrative agency. The nondelegation doctrine expresses the belief that lottery statutes abdicate the legislature's responsibility to make basic policy decisions and leave administrative discretion absolutely uncabined. ${ }^{82}$ The agency can easily meet any procedural requirements, give reasons, enunciate standards-in short, do whatever the courts want-while basing its actions exclusively on one of the statutory themes. The only meaningful judicial constraint on this type of discretion is a command by the court that the agency give appropriate weight to each statutory theme. ${ }^{83}$ If the statute states no weights, however, the agency may anticipate or respond to such a demand by simply declaring that it has taken account of all of them. The court may then respond, as the Supreme Court did in Overton Park, by saying, "Prove it." An alert agency can usually do so without in any way altering its choice among the themes.

In such situations, courts have two choices, both involving substantive judicial review. They may strike their own balance, declaring it the legislature's true intent. In the Benzene case, ${ }^{84}$ for example, the Supreme Court read a requirement of "significant risk" into the statute; the agency had to show such a risk before it could choose among a wide array of mixes of health and efficiency. ${ }^{85}$ Alternatively, courts can read the lottery out of the statute, claiming that the statute has a threshold single purpose. In Overton Park, for example, the Court denied that the statute set park preservation, neighborhood preservation, cost saving, and highway construction as goals with unspecified weightings and instead found that park preservation trumped the other statutory purposes. ${ }^{86}$ In short, precisely because lottery statutes give agencies unlimited discretion, courts are likely to deny that they are lottery statutes.

A great many cases concern the extent to which a statute encompasses

82. Aranson, Gellhorn \& Robinson, $A$ Theory of Legislative Delegation, 68 CORNELL L. REV. 1, 63-67 (1983); see also T. LOWI, THE END OF LIBERALISM: THE SECOND REPUBLIC OF THE UNITED STATES 94-107 (2d ed. 1979) (discussing evolution of delegation to the administrative process).

83. See Sierra Club v. Costle, 657 F.2d 298, 330 (D.C. Cir. 1981) (EPA "must exercise its discretion to choose an achievable emission level which represents the best balance of economic, environmental, and energy considerations"); Home Box Office, Inc. v. FCC, 567 F.2d 9, 35 (D.C. Cir. 1977) (court "must ensure both that the Commission has adequately considered all relevant factors ... and that it has demonstrated a 'rational connection between the facts found and the choice made" "), cert. denied, 434 U.S. 829 (1977).

84. Industrial Union Dep't, AFL-CIO v. American Petroleum Inst., 448 U.S. 607 (1980).

85. Id. at 639.

86. Citizens to Preserve Overton Park, Inc. v. Volpe, 401 U.S. 402, $412-13$ (1971). 
multiple unweighted goals or contains a paramount goal with offsetting goals whose precise degree of offset the legislature knows but cannot express in statutory language. As we approach the pure lottery, judicial checks on agency discretion are less and less defensible because there is no particular reason to prefer pure judicial discretion to pure agency discretion. The upswing in substantive review by the D.C. Circuit ${ }^{87}$ is in part a response to Vermont Yankee's ${ }^{88}$ limitations on further procedural regulation of informal agency action, but it also represents a substitution of judicial for administrative discretion where multi-purpose statutes require someone to exercise discretion. The only perfect solution to the problem of agency discretion in pure lotteries is for the legislature not to write lottery statutes in the first place.

The courts are going to find it particularly difficult to engage in substantive review in high-technology areas. Comparing detailed but somewhat vague statutory provisions with highly complex administrative regulations to determine whether the regulations are in accord with the statute promises to be a fruitless task. ${ }^{89}$ The courts' own demands that agencies act synoptically, gathering all facts and considering all alternatives and outcomes, will result in increasingly complex and technical rulemaking records. As national respect for the technocracy increases, and judges are more often faced with materials prepared by technocrats, that technocrats do understand and judges clearly cannot understand, courts will necessarily scale back their review: Courts cannot take a hard look at materials they cannot understand nor be partners to technocrats in a realm in which only technocrats speak the language. I think we should anticipate that in the future courts will be less, not more, successful at bringing thematic discretion under judicial control than they have been in the past.

\section{Decisions Under Conditions of High Uncertainty}

Sometimes both government action and inaction entail unknowable risks and unknowable benefits. Without any real indication of the effects of various alternatives, these situations appear to be ones of pure discretion: The decisionmaker faces a high and equal level of uncertainty about the outcome of each alternative and cannot avoid uncertainty by doing nothing. The agency can be controlled by various procedural and reason-

87. See, e.g., United Steelworkers v. Marshall, 647 F.2d 1189 (D.C. Cir. 1981) (making independent interpretations of statute and finding that agency flunked substantial evidence test for 38 of its rules); Alabama Power Co. v. Costle, 636 F.2d 323 (D.C. Cir. 1979) (flatly overruling agency's interpretation of statute).

88. Vermont Yankee Nuclear Power Corp. v. NRDC, 435 U.S. 519 (1978).

89. The difficulty of the attempt is illustrated by Alabama Power Co. v. Costle, 636 F.2d 323 (D.C. Cir. 1979). There, three judges each wrote a separate part of the court's opinion, which occupied 68 pages in the Federal Reporter. 
giving requirements, but these controls do not ultimately limit its discretion. Indeed, there seems to be neither a way of judicially limiting the agency's discretion nor reason to do so.

The Benzene case $^{30}$ provides a good example. At the time that OSHA made its decision on maximum workplace exposure levels, existing research could not tell which of a number of low exposure levels would harm workers. Research showed that benzene was a carcinogen at high dosages, but no one was able to draw "dose-response" curves for the low dosages that industrial workers commonly received. ${ }^{91}$ If OSHA did nothing until it knew which low level exposures were safe and which were unsafe, many deaths from cancer might occur. Similar damage would occur if OSHA set permissible levels too high. If OSHA set exposure levels too low, however, industry would have to spend millions on reducing exposures, and at least some marginal operators in some industries would be forced out. In effect, the agency had a purely discretionary choice between the one part per million level which was the lowest its instruments could measure and the ten parts per million level above which inferences from laboratory experiments were strong enough to establish a cancer risk.

Because administrative discretion cannot be subjected to judicial restraints in situations of high uncertainty, courts are likely to read congressional limitations into the statute. In the Benzene case, for example, the Court read into the statute a requirement that the agency establish "significant risk" for low-level benzene exposure before it set a maximum exposure level..$^{22}$ In effect, this is a directive to the agency to resolve the high uncertainty about low-level exposures in favor of cost-saving and against worker safety until uncertainties can be substantially reduced. Thus Congress, through the mouth of the Court, strips the agency of its discretion.

The "significant risk" holding is a specific example of a more general mode of limiting agency discretion. Where uncertainties are very high, whoever bears the burden of proof loses. Congress and the courts may limit discretion by creating burdens of proof and assigning them to whatever purpose, interest, or value they least favor..$^{93}$ Such assignments of the burden of proof eliminate uncertainty in the short run; in the long term, they are self-liquidating because as uncertainties disappear the burden of proof can be met. Nevertheless, we may prefer the best guess of an expert free to choose among a wide range of alternatives to an abstract

90. Industrial Union Dep't, AFL-GIO v. American Petroleum Inst., 448 U.S. 607 (1980).

91. Id. at $620,631-32$.

92. Id. at $639-40$.

93. See MacIntyre, A Court Quietly Rewrote the Federal Pesticide Statute, LAW \& PoL'Y Q. (forthcoming). 
and more or less dichotomous choice made by Congress or the courts. In any event, as the influence of technocratic administration increases, it will become more difficult for judges to fault an agency's choice among alternatives that all involve complex and nearly equal technical uncertainties.

In his contribution to this Symposium, Professor Yellin suggests beefing up the requirement that reasons be given when an agency confronts high uncertainties. $^{94}$ In American Petroleum Institute v. Costle, ${ }^{95}$ the D.C. Circuit noted that the EPA faced grave uncertainties in setting ambient standards for ozone and held that an acknowledgment of the uncertainties and an explanation of why they were resolved as they were would be sufficient to meet the substantial evidence requirement of the statute involved. ${ }^{96}$ Perhaps acknowledgment and explanation is about the only limitation courts can honestly place on discretion created by uncertainty, since any more substantively based standard of review merely shifts the locus of discretion to the courts.

This type of administrative discretion, like the others described here, involves a variant of the familiar line-drawing problem. Whether the permissible deviation from one person, one vote in order to maintain traditional boundaries should be eight or nine percent, or the minimum permissible level of peanuts in peanut butter should be 90 percent or 87 percent, or the permissible variation from a twelve person jury should stop at six or five, ${ }^{97}$ is arbitrary, either because the cost-benefit gradient is so smooth that no particular stopping point appears better than the next or because the uncertainty about the effects of small changes is very high. Courts tend to deny discretion either by resorting to pseudo-science to prove that there are jumps in the cost-benefit gradient or by assigning burdens of proof.

\section{The Discretion to Initiate Action}

Administrative discretion to initiate or not to initiate action might be broken into two categories: the initiation of adjudications and the initiation of rulemaking proceedings or other policymaking actions. The former is closely analogous to prosecutorial discretion. Administrative agencies typically enjoy enforcement resources far too limited to bring adjudicatory actions against all worthy candidates. As Richard Stewart and Cass Sunstein have pointed out, this situation is about as pure an instance of "no

94. Yellin, supra note 63, at 1321-24, 1326.

95. 665 F.2d 1176 (D.C. Cir. 1981).

96. Id. at 1186-87.

97. See Ballew v. Georgia, 435 U.S. 223, 234-35 (1978). In Ballew, the Court found six-person juries substantially better than five-person juries by relying on one study based on untestable assumptions. 
law to apply" as one can find because, except in those rare instances where Congress has absolutely mandated enforcement, there is no law telling the agency which malefactors it should single out for investment of its scarce prosecutorial resources. ${ }^{98}$ Initiation of rulemaking might, in contrast, be analogized to congressional discretion to make or not to make laws since rulemaking is an exercise of Congress' delegated lawmaking power. Here, too, there is no law to apply in the sense that, aside from constitutional limitations, there is no control over which bills Congress should or should not consider.

The analogy is, however, incomplete. It is true that in many instances the delegation is so broad that the agency is placed very much in the position of a legislative body with a limited capacity to make laws and an almost infinite range of lawmaking options. In other instances, however, Congress states relatively clear and limited goals, and rulemaking partakes more of enforcement than of lawmaking. Particularly over time, as the agency builds up its body of rules, the next item on the agency's agenda may become clearer and clearer and the agency's rulemaking resources may appear more and more adequate to meet its remaining agenda. Given the stated goals of various environmental statutes, for example, there came a time when the Environmental Protection Agency would have appeared quite derelict in its duties if it had not initiated rules on atmospheric lead pollution.

Precisely because rulemaking is often a form of wholesale enforcement, the existence of rulemaking authority may actually reduce an enforcement agency's discretion because it brings the agency's resources more into line with its obligations. ${ }^{9 \theta}$ Once the Federal Trade Commission moved to rules specifying industry-wide unfair practices, one could at least begin to argue that particular industries should head the list for regulation. That argument will become more and more persuasive over time as the body of rules increases so that the quantum of remaining practices to be regulated appears smaller and smaller in relation to the Commission's capacity for regulation.

Thus, discretion in the initiation of rules and probably of such informal actions as planning decisions, can be constrained by relatively precise congressional statements of goals and by the cumulative effects of the agency's

98. See Stewart \& Sunstein, Public Programs and Private Rights, 91 HARV. L. REV. 1195, 128586 (1982).

99. For example, when the FTC's enforcement efforts consisted primarily of unfair trade practice cases brought against individual firms, it occupied a position akin to that of a criminal prosecutor: The number of possible unfair trade practices was immensely greater than the number of adjudicative proceedings the agency could initiate. When it began to employ rulemaking instead, see National Petroleum Refiners Ass'n v. FTC, 482 F.2d 672 (D.C. Cir. 1973), cert. denied, 415 U.S. 951 (1974), the Commission's reach was vastly extended. 
own previous rulemaking activity. Aside from authorizing and encouraging enforcement by rulemaking, it is much more difficult to constrain enforcement discretion wielded in the initiation of adjudications. The legislature may pick out a few items of mandatory prosecution and provide the money that makes it possible to meet the mandate. Lawmakers may also place certain negative checks on enforcement discretion, such as forbidding agencies to enforce in a racially discriminatory way. Short of providing far higher budgets to the agencies than it is likely to appropriate, however, Congress by necessity will continue to leave many "no law" situations.

Stewart and Sunstein have suggested that administrative discretion not to initiate various actions has now been checked by a body of judge-made and statutory private rights of initiation. Where agencies do not initiate action when they should, private persons may challenge those negative exercises of discretion in the courts. ${ }^{100}$ The authors' data and arguments are complex, and their enthusiasm for this mode of limiting discretion is carefully bounded and qualified; no brief summary can do justice to their position. Nonetheless, the bottom line seems to be that in most instances the limit imposed on discretion would be the rather weak one of a reasongiving requirement. In the trial of private right-of-initiation suits, courts would require that the agency give reasons for not initiating action. Only where a statute clearly mandates action or specifically condemns certain inactions, such as inactions resulting in racial discrimination, would a court order the agency to initiate action. ${ }^{101}$

Particularly in those situations where the agency comes closest to meeting the conditions of the analogy of prosecutorial discretion on the one hand or of Congressional lawmaking discretion on the other, private rights of initiation have probably not yet developed far enough to constitute a definitive check on discretion. Only under bizarrely favorable procedural circumstances are courts likely to order an agency to promulgate regulations. ${ }^{102}$ Stewart and Sunstein themselves are anxious to hedge private rights to control agency prosecutorial discretion, lest private priorities be allowed to disrupt public ones. ${ }^{103}$

100. Stewart \& Sunstein, supra note 98 , at 1267-89; see also J. MASHAW, INTRODUCTION TO THE AMERICAN PUBLIC LAW SYSTEM: CASES AND MATERIALS 962-1021 (1975) (discussing implied private rights of action and "citizen" enforcement of regulatory statutes).

101. See Stewart \& Sunstein, supra note 98, at 1279.

102. See State Farm Mut. Ins. Co. v. Department of Transp., 680 F.2d 206 (D.C. Cir. 1982) (requiring promulgation of airbag regulations by National Highway Traffic Safety Administration in face of second order to rescind by Secretary of Transportation), vacated 103 S.Ct. 2856 (1983).

103. Stewart \& Sunstein, supra note 98 , at $1267-89$. 


\section{B. The New Discretion}

A number of commentators on administrative law have recently suggested the creation of new modes of agency action. These new modes will create new reservoirs of agency discretion. In this section, I discuss how such discretion would operate and how courts may respond to it.

\section{Negotiation, Mediation, and Arbitration}

Richard Stewart proposes that agencies shift away from adjudication and rulemaking and toward more cooperative forms of regulation. ${ }^{104}$ In Stewart's scheme, discretion can be a tool for overcoming resistance from entrenched interests in both policymaking and implementation. ${ }^{105}$ Sometimes, regulated groups may resist implementation so strongly that they drive implementation costs up above levels acceptable to the regulator. In such cases, agencies can be granted discretion to seek less than full compliance with a law in order to reduce the costs of implementation. Such discretion must be relatively unbounded because it is precisely the resister's inability to predict the agency's response that will move it to reach a negotiated settlement. ${ }^{108}$

Judicial review poses serious difficulties for the exercise of this form of discretion. First, the availability of review itself changes the terms of the game in ways that may be adverse to the government negotiator. ${ }^{107}$ Second, judges may strike down an agency's choice of less than full enforcement in return for cooperation. ${ }^{108}$ Where an agency tempers its demands in order to avoid amendments to its organic act, the bargain may appear particularly unsavory. ${ }^{108}$

If courts see a range of individual degrees of compliance conformations

104. See Stewart, supra note 40, at 1341-53; see also Harter, Negotiating Regulations: A Cure for the Malaise, 71 GEO. L.J. 1 (1982) (proposing negotiating as supplemental rulemaking procedure).

105. Stewart, supra note 40 , at $1372-73$.

106. See T. Schelling, THE STRATEgY OF CONFLICT 131-39 (1960).

107. Private parties have two major advantages: (1) If they do not like the outcome of the first game, they may play again by challenging the legitimacy of the negotiated outcome in a subsequent court action; (2) they can threaten such a replay during the first game and demand extra concessions from the government as the price of not suing.

108. Where a statutory standard such as the requirement of a safe workplace exists, courts may see the agency as violating its duty to achieve the standard by settling for partial fulfillment in a particular instance. Cf. American Textile Mfrs. Inst. v. Donovan, 452 U.S. 490, 510-12 (1981) (promulgation of OSHA regulations should be guided by feasibility of ensuring employee health rather than by cost-benefit analysis). In addition, negotiation might conflict with rules against ex parte contacts and restrictions in the Federal Advisory Committee Act, 5 U.S.C. app. §§ 1-15 (1982). See Harter, supra note 104, at 33-34; Stewart, supra note 40, at 1344-50.

109. In effect, the agency is yielding to threats that if it fully enforces the statute, the regulated interests involved will go to Congress and get the statute amended in their favor. While everyone would agree that it is legitimate for the regulated interests to appeal to Congress, not everyone would agree that it was legitimate for the agency to reduce enforcement to head off such appeals. 
that fall within the demands of the statute, they may uphold negotiation of each individual conformation. The very fact of a negotiated settlement, however, is likely to persuade judges (and the public) that there was a "correct" legal rule or level of implementation and that the agency's negotiations gave it away. ${ }^{110}$

These considerations are further complicated when the agency is not itself directly involved in negotiations but instead is ratifying a mediated settlement among interested parties. ${ }^{111}$ Discretion not to approve a mediated settlement is likely to be subject at most to the requirement that reasons be given. Exercising discretion to ratify a private agreement might be subject to a higher level of judicial review because it involves public enforcement of a private agreement. ${ }^{112}$

As rulemaking has become more a form of multi-party adjudication, more time-consuming, and more subject to judicial scrutiny, there has been increasing interest in negotiating processes that would arrive at an agreed-upon policy. Commentators like Stewart who espouse negotiation have argued for less searching review of negotiated outcomes. ${ }^{113}$ But how can we be sure that the agency has not given the store away in the course of negotiations? In many instances, of course, enough opposing interest groups will have participated to ensure that the agency has not given away any version of the store. In other instances, however, the structure of the bargaining conflict may leave the "public interest" unrepresented by anyone but the agency. ${ }^{114}$ If we do not employ judicial review to check administrative discretion in negotiation, how can it be checked? Of course, Congress could theoretically formulate a new standard for reviewing in-

110. If the higher level of enforcement were not "correct," the argument is likely to run, why would the regulated party refrain from challenging it in court rather than offering something (i.e., negotiating) to get it lowered?

111. Some schemes for environmental mediation, for instance, provide that developers and environmental interests work out their own settlement, which is then submitted to the relevant government agency for approval. See Harter, supra note 104, at 40-42; Lee, Defining Success in Environmental Dispute Resolution, RESOLVE, Spring 1982, at 1 .

112. Although the application of the non-delegation doctrine in Schechter Poultry Corp. v. United States, 295 U.S. 495 (1935), technically involved a delegation from Congress to the President, it was clearly the delegation of public power to private groups at the heart of the NIRA that most troubled the Court. Id. at 537 (delegation of legislative authority to trade associations or industrial associations "is unknown to our law and is utterly inconsistent with the constitutional prerogatives and duties of Congress").

113. See Stewart, supra note 40 , at 1348 .

114. Where one side is well-organized and the other is a diffuse, ill-organized interest, such as used-car buyers or carpentry hobbyists, there will be little or no interest-group check on the government's negotiations with the well organized side. Cf. New Motor Vehicle Bd. v. Orrin W. Fox Co., 439 U.S. 96 (1978) (upholding California statute that allowed existing car dealers effectively to block market entry by using objections process); Mashaw, Constitutional Deregulation: Notes Toward a Public, Public Law, 54 TULANE L. REv. 849 (1980) (discussing interest-group influence on administrative law). Stewart recommends public funding of public interest groups to address this problem. Stewart, supra note 40 , at $1350-51$. 
formal, negotiated agency action. I doubt, however, that judges would pay much attention to such an expression of congressional mood standing by itself.

One idea worth exploring is the employment of "reserve prices." Experts on bargain theory argue that one should always enter a bargaining session having in mind an outcome below which one will not be prepared to complete a bargain. ${ }^{115}$ In some cases, a precise dollar reserve price can be set. In others, a reserve price can only be stated so vaguely that it is meaningless as a guide to action. It is possible, however, to envision some areas of government action-for instance, the setting of water purity standards-in which the statute could set a reserve price or minimum standard below which the agency could not accept a negotiated outcome, but authorize the agency to set a much higher standard in a notice-andcomment proceeding. Under such a scheme, courts might be persuaded to curtail their review of negotiations because the agency's negotiating discretion would already have been constrained by statute.

It is difficult to say whether or not the bargaining process would be sharply skewed against the agency because its reserve price was known by the other players while theirs would be unrevealed.116 Still, there are strategies an agency could use to improve its position. It might announce before bargaining that it had itself set a goal of exceeding the statutory reserve price in at least half of its negotiations, and that it would reject a bargain and go to rulemaking in any particular proceeding if it felt that settling for its reserve price in that proceeding would place its goal in danger. In other words, the agency could set a secret reserve price above the statutory reserve price but not below it. Thus, Congress could constrain agency discretion and the agency could maintain much of its bargaining power. Particularly where Congress is interested in "technology forcing," the combination of a reserve price and a "bargaining-upward" arrangement may be preferable to setting unrealistic statutory standards from which Congress itself must subsequently bargain a retreat. ${ }^{\mathbf{1 1 7}}$

If we move from bargaining before rulemaking to enforcement bargaining, we come closer to prosecutorial discretion in conventional law enforcement. Agencies such as OSHA or EPA have limited enforcement resources and may prefer to offer something in the way of reduced

115. See H. RAIFFA, THE ART AND ScIENGe OF NEgOTIATING 45 (1982) (describing reserve prices as a natural feature of negotiation).

116. As a purely theoretical matter, all other things being equal, it no doubt would be. But when the government is a player, all other things are rarely equal.

117. See State Farm Mut. Ins. Co. v. Department of Trans., 680 F.2d 206, 210-11 (D.C. Cir. 1982) (discussing Congress' overruling of NHTSA's ignition interlock requirement), vacated, 103 S.Ct. 2856 (1983). 
enforcement as an inducement to voluntary compliance. ${ }^{118}$ Of course, agencies may sometimes prefer to bargain for another reason altogether. They may fear that full enforcement will mobilize sufficient political opposition to lead to congressional amendment of the statutes authorizing their programs. ${ }^{119}$ Most of us, and surely most courts, would find an explicit use of such "prudential" discretion illegitimate. In practice, such discretion may not be clearly identifiable. Regulated entities can engage in a wide range of resistance to agency activity. They can seek full administrative and judicial review; they can lobby Congress to curtail the agency's power. ${ }^{120}$ If an agency is entitled to take into account the degree to which its scarce resources will be consumed in responding to other modes of resistance, why shouldn't it take account of the drain on its resources that a defensive lobbying campaign in Congress will cause?

There has, however, been a tendency, both in statutory and case law, to treat regulatory benefits as entitlements. ${ }^{121}$ Under OSHA, for example, courts might discover an entitlement to a safe workplace. ${ }^{122}$ This approach tends to treat enforcement discretion as illegitimate and to demand full enforcement of the entitlement. Thus, there is a growing interest in private actions to challenge agency failure to initiate full enforcement proceedings or to challenge agency settlements, despite the traditional view that the agency's behavior resembles prosecutorial discretion. ${ }^{123}$

This tendency is fueled by the ease with which "political" considerations may be confounded with considerations of scarcity. A particular administration may underenforce a particular program not because its resources are scarce but because it does not believe in the program, or at least not in the version of the program created by the rulemaking of the previous administration. ${ }^{124}$ If a new administration proceeds to offer reduced enforcement for voluntary compliance, it will claim scarcity. Its opponents will charge that it is modifying the program, not through aboveboard resort to new rulemaking proceedings or requests to Congress to

118. Such a suggestion is made in E. BARDACH \& R. KAGAN, GONG BY THE BOOK: THE PROBLEM OF REGULATORY UNREASONABLENESS 135-40 (1982).

119. The well-known saga of the FTC shows the perils of not giving in to such fears. See Weingast \& Moran, The Myth of Runaway Bureaucracy-The Case of the F.T.C., REGULATION, May/ June 1982, at 33 .

120. Id.

121. See Stewart \& Sunstein, supra note 98, at 1208-20, 1271-75.

122. Stewart argues against such a discovery in Paradoxes of Liberty, Integrity and Fraternity: The Collective Nature of Environmental Quality and Judicial Review of Administrative Action, 7 ENVTL. L. 463 (1977).

123. See Mashaw, "Rights" in the Federal Administrative State 92 YALE L.J. 1129, 1170 (1983); Stewart \& Sunstein, supra note 98, at 1197.

124. See State Farm Mut. Ins. Co. v. Department of Trans., 680 F.2d 206 (D.C. Cir. 1982), vacated, 103 S.Ct. 2856 (1983). 
amend the statute, but through devious underenforcement disguised as enforcement bargaining.

Faced with these problems, courts have a number of alternatives. They may create additional enforcement entitlements. They may decide whether the agency's true goal is deliberate underenforcement designed to undermine statutory mandates or bargaining to get more bang for the enforcement buck. Or they may adhere to the traditional analogy of prosecutorial discretion. The first alternative runs the risk that whoever gets to the courthouse door first will obtain full enforcement of his particular entitlements no matter what the cost and thus reduce excessively the enforcement resources available for the protection of others' entitlements. ${ }^{125}$ The second option raises the root problem of discretion-probing the true intentions of the administrator. ${ }^{126} \mathrm{~A}$ requirement that reasons be given is likely to lead to routine formulas about insufficient enforcement budgets. The third alternative leaves us no way to determine whether the agency is trading reduced enforcement for voluntary compliance in order to stretch its enforcement dollars or is not fully enforcing the statute for some less acceptable reason.

Some agencies absolutely eschew enforcement discretion; OSHA, for instance, tells its inspectors to write up every violation. ${ }^{127}$ Where some enforcement bargaining appears desirable, it is probably easiest to limit discretion by specifying in organic statutes the agenda and terms of bargaining; otherwise, any lapse in agency enforcement can be excused as an implicit bargain. The simplest form of bargaining may be a joint agency-enterprise agreement to a time-staged compliance plan explicitly displaying the tradeoffs between voluntary compliance and enforcement delay. In addition, the statute or the courts may require an agency to establish rules setting the general terms of tradeoffs between voluntary compliance and enforcement delay. The "blue book" with which assistant prosecutors work in some large district attorney's offices exemplifies such constrained discretion. ${ }^{128}$ In effect, it sets reserve prices below which a prosecutor cannot go. If offered less, he or she must seek full-or, in the agency context, immediate-enforcement.

Such deliberately structured bargaining in which the quid pro quo and

125. See Stewart \& Sunstein, supra note 98, at 1292-93.

126. See Jaffe, The Illusion of the Ideal Administration, 86 HARV. L. REV. 1183, 1196-97 (1973); Nathanson, Probing the Mind of the Administration: Hearing Variations and Standards of Judicial Review Under the Administrative Procedure Act and Other Federal Statutes, 75 COLUM. L. REV. 721, 722-33 (1975).

127. See E. BARDACH \& R. KAGAN, supra note 118 , at 56.

128. See Vorenberg, Decent Restraint of Prosecutorial Discretion, 94 HARV. L. REV. 1521, 156265 (1981). Specific practices come and go as elected district attorneys come and go, but usually involved is a set of instructions from the head of the agency as to how far a charge may be reduced under particular circumstances without special permission from a supervisor. 
the reserve price are matters of public record could provide adequate restraints on discretion without judicial review. Where bargaining is not so carefully structured, however, it is difficult to see what courts can do except either start down the Overton Park path of motive review or abandon review altogether by invoking the analogy to prosecutorial discretion.

Overton Park, however, very much reflects the glorification of the judge as lay representative, and the disdain for both group politics and technocracy, of the 1960's and 1970's. Moreover, in Overton Park the Department of Transportation did not even attempt a technical screen for its simple, essentially political decision to accept the solution propounded by a local government. In a more technocratic era in which agencies have learned to justify each bargain in terms of the long-term pursuit of maximum technical and economic rationality, courts may be reluctant to spot clear errors. Courts may be quite content if an agency can give reasons for the bargains it has struck.

\section{Agency Delegation}

In a recent book, Bruce Ackerman and William Hassler advocate a variant of the New Deal's image of discretion vested in expert agencies that pursue broadly stated goals set by Congress. ${ }^{129}$ They suggest that Congress set only time-staged performance goals, such as increasing life expectancy by one percent at the end of ten years. ${ }^{130}$ The goal having been set, and the lawmaking power having been delegated, the agency would then have almost unlimited discretion in deciding how to meet that target. Such technocratic proposals reflect society's swing back toward a greater respect for expertise. This shift toward technocracy, however, is bound to be greatly tempered both by the long-term trend toward bringing the executive branch's actions under legal control and by the increasing disenchantment with regulation by command. Thus, it may be to Stephen Breyer's proposals for regulatory reform that we must turn to give content to Ackerman's vision.

Breyer proposes that in many areas of regulation the agency should set performance standards or output goals, and leave the instrumental decisions to those regulated. ${ }^{131}$ Combining the proposal of Ackerman and Hassler with that of Breyer may produce a system of "sub-specification." For example, Congress may command an agency to save 10,000 lives by 1995. The agency may decide that the best way to save those lives by 1995 is to reduce lead pollution levels to $X$. It might then assign to each source,

129. B. ACKERMAN \& W. HASSLER, supra note 39.

130. See id. at 126.

131. See Breyer, Analyzing Regulatory Failure: Mismatches, Less Restrictive Alternatives and Reform, 92 HARV. L. REV. 549 (1979). 
each corporation, or each industry an annual pollution-reduction target. If the agency were to assign targets to collective entities, then each entity would presumably subspecify targets to each individual source. These individual sources would then choose their own technology and/or transfer of pollution rights.

Viewed independently from Breyer, Ackerman and Hassler appear to be vesting great discretion in the agencies. Combining the proposal of Ackerman with that of Breyer, one might view the result as virtually eliminating both policymaking and implementation discretion from the agency; the combined proposal vests policy discretion almost entirely in the legislature and implementation discretion almost entirely in the market. Ultimately, individual firms would make market-dictated choices among the alternative means available to meet their assigned goals. Implementation discretion rests at whatever level makes actual instrumental choices. This assignment of discretion may raise Schechter-type problems, ${ }^{132}$ since it is unclear why the decentralization of discretion to private groups is a good thing. Under the Ackerman-Hassler-Breyer scheme, cartels rather like the old NIRA cartels may be making crucial allocation decisions, and we have no more reason to trust those cartels now than we did then. ${ }^{133}$ Of course, Congress or the agencies might eliminate the cartel problem by creating specialized sections within the agency to assign particularized performance goals to individual firms. Such highly particularized performance goals, however, might be as rigid and inefficient as command and process standards. The alternative is the market, with the specialized agency sections assigning marketable entitlements or duties to particular enterprises which in turn would buy and sell so as to reach efficient solutions. ${ }^{134}$

Even if most implementation discretion can ultimately be returned to the market, a great deal of discretion will probably remain in the process of setting subgoals, time-staging them, and allocating them among various enterprises. It is almost impossible to believe that such sub-allocation could be done by agency fiat or by an internal agency "planning" process that was purely discretionary. Sub-allocation would almost certainly require notice-and-comment rulemaking. ${ }^{135}$ Solving the problems caused by

132. See supra note 112 .

133. Industry-wide targets could only be assigned to trade associations or ad hoc committees, where the assignment of sub-targets to particular companies or plants might become the occasion for anti-competitive maneuvers. See Liebmann, Delegation to Private Parties in American Constitutional Law, 50 IND. L.J. 650, 708 (1975).

134. Various proposals for assigning marketable air and water pollution rights are examples. See, e.g., Calvo y Gonzalez, Markets in Air: Problems and Prospects of Controlled Trading, 5 HaRV. ENVTL. L. REV. 377 (1981); Note, Technology-Based Emission and Effluent Standards and the Achievement of Ambient Environmental Objectives, 91 YALE L.J. 792 (1982).

135. The sub-allocation decisions would be so important to management and labor, as well as 
discretion may be possible only at the cost of suffering many of the rigidities and delays that now accompany rulemaking. This rulemaking process would closely resemble the legislative process. Ultimately, Ackerman and Hassler's call for agency discretion comes down to the belief, stated clearly in their book, ${ }^{136}$ that the federal bureaucracy is a far better legislator than is Congress. The Ackerman-Hassler-Breyer proposal, then, is not so much a call for increasing administrative discretion as for shifting as much discretion as possible to individual enterprises under market constraints and shifting lawmaking from statute-making in Congress to rulemaking in the executive branch. If my prognostication about sub-allocations being done by rulemaking is correct, then determining the value of the AckermanHassler proposal does not mean comparing the merits of rules to those of discretion, but comparing the merits of statute-making to those of rulemaking as an alternative legislative process. If Congress sets only long-term, general goals, however, we are faced once again with the problems raised in my discussion of thematic statutes. ${ }^{137}$ Faced with a truly blank ends-forcing statute, courts will not easily be able to read in thresholds or priorities. If courts therefore assign high burdens of proof to agencies and require them to prove that their particular allocations will meet Congressional targets, the rulemaking process will be further rigidified.

To the extent that the agencies proceeding under ends-forcing statutes can avoid rulemaking, a good deal of sub-allocation will probably be done through negotiation. The problems with that form of discretion, are, as we have seen, rather troubling.

\section{Conclusion}

I have noted that administrative law has entered a period in which the two long-term tendencies that influence its development are pushing in opposite directions. On the one hand, the courts are trying to catch up with and limit agency discretion in the same way that they previously harnessed agency adjudication and rulemaking. On the other, a reemerging respect for technocrats, accompanied by growing disillusionment with interest group pluralist democracy, leaves judges in an increasingly poor position to impose such rules. At the start of their great leap forward in the 1960's, judges were not only lay heroes against the technocrats, but

consumers and local environmental interests, that they would all have a strong claim to the kind of participation in decisionmaking that we have come to accommodate through notice-and-comment proceedings. See K. DAVIS, supra note 12 , at 66 (notice-and-comment rulemaking is "most democratic of procedures").

136. B. ACKERMAN \& W. HASSLER, supra note 39 , at 116-21.

137. See supra pp. 1505-07. 
enforcers of the dominant group theory of democracy. By the 1970's, courts were trying to cure the increasingly noted pathology of group politics by insisting that the rulemaker listen to and respond to every argument put forward by every group. By about 1980, courts required instead that an agency consider all the facts and arguments that ought to be considered. ${ }^{138}$ The former is an insistence that government submit itself to democratic processes; the latter is an insistence that it act rationally or scientifically. To make the latter demand, however, at a time when technicians are regaining their ascendancy over laymen, is for judges a peculiarly self-destructive stance: It places judicial review on precisely the ground on which the judge-as-layman is particularly unqualified and the technocrat is particularly qualified-the technical, scientific, and economic correctness of the decisions reached by the agencies. Nor is this situation static. As courts demand records that document synoptic decisionmaking, the agencies will learn to present records of greater and greater complexity. As courts are confronted with more and more technically complex records, judges as lay heroes will seem to themselves, and appear to others, less and less heroic. Thus, at a time when judges might be preparing to move into the next area of administrative practice to be legalized, they may be feeling far less capable of judicial activism than they have felt in the last few decades. The demand for synopticism is itself the greatest attack on discretion, for it denies that discretion exists to choose any but a single "right" answer. At the same time, an administrative record armored in comprehensiveness is likely to be the best shield behind which agency discretion can hide.

Given these cross-cutting tendencies, we need not expect a great judicial crusade against discretion. Indeed, in certain areas, such as the discretion entailed in regulatory negotiation and the setting and sub-specification of general, long-term performance goals involved in the Ackerman-HasslerBreyer proposal, we might expect gains rather than losses for discretion. In areas that combine high technology with high uncertainty, judges may demand that agencies demonstrate that they have acted as synoptically as possible, that agencies clearly identify areas of high uncertainty, and that agencies give reasons for electing the strategies they do elect in the face of that uncertainty. Such judicial demands will increase decisionmaking costs, but ultimately will do little to curtail discretion. The more activist judges will try to go further. We may expect some instances in which judges employ statutory interpretation to undercut agency decisions with which they disagree in their assignments of burdens of proof under conditions of high uncertainty or in line-drawing situations.

138. See Diver, supra note 60 , at $409-13$. 
The area of waivers or exemptions is one I would put forth as a prospective battleground. There seems likely to be increased interest in private causes of action to challenge waivers, and increased judicial sensitivity to pseudo-waivers leading to more demands that waivers be accomplished through "hybrid" proceedings which involve relatively easy access to third parties and approach full-scale adversary proceedings.

Thematic or lottery statutes, and the problems of the discretion that accompany them, also seem unlikely to disappear. When a statute is genuinely underdetermined, there is no legitimate mode of judicial control over agency discretion. It is difficult to predict the extent to which judges will "cure" their institutional incapacity by resorting to statutory interpretations that set firm priorities in the face of congressional waffling. If I am correct in predicting that the next few decades will witness some judicial retreat as technocracy flourishes, we might not expect a major growth in judicial control of this area of discretion.

It is in the first three areas of discretion I discussed-distributive decisions; high-volume, low-level decisions; and subtle and complex assessments of human characteristics-that I expect the thrust toward judicial review of informal agency action to conflict most strongly with the contrary pressures set up by the resurgence of technocracy. In part through the demand for substantive and procedural rules, and in part through requirements that reasons be given, we are likely to see more restraint on the kind of administrative discretion that flourishes when large numbers of small distributive decisions requiring individualized judgments must be made. Courts will place increasing pressure on agencies that defend discretion on the grounds of subtlety, complexity, and particularity of administrative decisions to prove that these agencies have the organization, personnel, and information necessary to make such decisions. Our new electronic capacity for storing, retrieving, and analyzing millions of small decisions has already resulted in demands that agencies follow their own past decisions. Stricter requirements to follow precedent, rather than the proliferation of procedural rules, may become the major vehicle for limiting these areas of discretion over the next few years. If so, requirements that reasons be given will also proliferate, both because reasoned opinions are necessary for determining what counts as a precedent, and because the only way to allow an agency flexibility under such a regime is to allow it to deviate from precedent when it can give reasons for doing so.

It is distressingly clear to teachers of administrative law that they may have no subject matter to teach, that administrative procedure may be determined largely by the agency or even the policy involved. I certainly do not expect a uniform judicial or congressional reaction to the many forms of discretion. Particularly in high-technology areas, courts are likely to 
pause in any forward march toward limiting discretion. In other areas, especially where large numbers of small claims involving common human problems are central, the tendency for rules to catch up with administration is likely to continue. 